\title{
Processes, Challenges and Optimisation of Rum Production from Molasses-A Contemporary Review
}

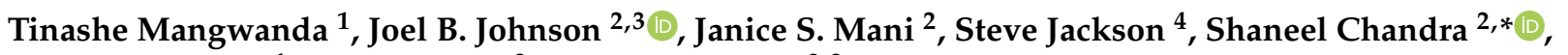 \\ Tyryn McKeown ${ }^{4}$, Simon White ${ }^{3}$ and Mani Naiker ${ }^{2,3, *}$ \\ 1 Delta Beverages-Sorghum Beer Manufacturing Plant, 1257 Mineral Road, Masvingo 263, Zimbabwe; \\ twmangwanda@gmail.com \\ 2 College of Science and Sustainability, CQUniversity, Bruce Hwy, North Rockhampton, QLD 4701, Australia; \\ joel.johnson@cqumail.com (J.B.J.); janice.mani@gmail.com (J.S.M.) \\ 3 Institute for Future Farming Systems, CQUniversity, Bundaberg, QLD 4670, Australia; s.c.white@cqu.edu.au \\ 4 Bundaberg Rum Distillery, Whitred Street, Bundaberg, QLD 4670, Australia; Steve.Jackson@diageo.com (S.J.); \\ Tyryn.McKeown@diageo.com (T.M.) \\ * Correspondence: s.chandra@cqu.edu.au (S.C.); m.naiker@cqu.edu.au (M.N.)
}

Citation: Mangwanda, T.; Johnson, J.B.; Mani, J.S.; Jackson, S.; Chandra, S.; McKeown, T.; White, S.; Naiker, M. Processes, Challenges and Optimisation of Rum Production from Molasses-A Contemporary Review. Fermentation 2021, 7, 21. https://doi.org/ $10.3390 /$ fermentation7010021

Received: 4 January 2021

Accepted: 4 February 2021

Published: 8 February 202

Publisher's Note: MDPI stays neutral with regard to jurisdictional claims in published maps and institutional affiliations.

Copyright: (c) 2021 by the authors. Licensee MDPI, Basel, Switzerland. This article is an open access article distributed under the terms and conditions of the Creative Commons Attribution (CC BY) license (https:// creativecommons.org/licenses/by/ $4.0 /)$.

\begin{abstract}
The rum industry is currently worth USD 16 billion, with production concentrated in tropical countries of the Caribbean and Asia-Pacific regions. The primary feedstock for rum production is sugar cane molasses, a by-product of sugar refineries. The main variables known to affect rum quality include the composition of the molasses, the length of fermentation, and the type of barrels and length of time used for aging the rum. The goal of this review is to provide an overview of the impact of these variables on rum quality, and to highlight current challenges and opportunities in the production of rum from molasses. In order to achieve this, we review the relevant contemporary scientific literature on these topics. The major contemporary challenges in the rum production industry include minimising the effects of variability in feedstock quality, ensuring the fermentation process runs to completion, preventing microbial contamination, and the selection and maintenance of yeast strains providing optimum ethanol production. Stringent quality management practices are required to ensure consistency in the quality and organoleptic properties of the rum from batch to batch. Further research is required to fully understand the influences of many of these variables on the final quality of the rum produced.
\end{abstract}

Keywords: ethanol content; molasses; fermentable sugars; fermentation; flavour; volatiles

\section{Introduction \\ 1.1. Definition of Rum}

Rum is a distilled alcoholic beverage primarily made from sugar cane molasses [1]. It may also be made from fermented cane juice or syrup [2,3]; however, the focus of this review is specifically on rum made from sugar cane molasses. Rum production evolved as a side product of the cane sugar industry in the 16th century, primarily in the Caribbean and West Indies regions. Initially beginning as a poor quality, inexpensive distilled spirit produced and consumed by sugarcane plantation slaves, this beverage was associated with low social economic status for several centuries [4]. It even played a significant historical role in the only military coup to occur in Australia, the "Rum Rebellion", in which Governor William Bligh was overthrown in part due to his attempt to abolish the use of rum as a method of payment [5]. However, with improved product quality and social acceptability in the 19th and 20th centuries, rum is now produced as a significant stand-alone commodity in many countries across the globe, including Australia [6].

The etymological origin of the word "rum" is unclear, with some authors suggesting that the term is derived from "Saccharum", the generic name of sugar cane (Saccharum officinarum L.). Another derivation could be from the word "rumbustion", British slang 
for a "great tumult or uproar" [7]. A more likely origin is "rumbullion", a term used to describe a beverage boiled from sugar cane stalks [7]. However, both terms were first reported at around the same time as the origin of the word "rum" itself [7].

In accordance with their food and beverage legislation, several countries have developed specific guidelines for which beverages are considered to be classed as rum. Examples of these definitions are provided below for Australia, the United States of America (USA), the European Union and the Caribbean Islands.

In Australia, rum is defined by Food Standards Australia and New Zealand (FSANZ) as:

'a potable alcoholic distillate, which, unless otherwise required, contains at least $37 \%$ alcohol by volume, produced by distillation of fermented liquor derived from food sources, so as to have the taste, aroma and other characteristics generally attributable to rum.' [8]. Legislation in the Excise Act 1901 further stipulates that for Australian manufactured goods:

'Rum means a spirit obtained by the distillation of a fermented liquor derived from the products of sugar cane, being distillation carried out in such a manner that the spirit possesses the taste, aroma and other characteristics generally attributed to rum.' [9]

In the USA, rum is defined as:

'an alcoholic distillate from the fermented juice of sugar cane, sugar cane syrup, sugar cane molasses, or other sugar cane by-products, produced at less than 190 proof in such manner that the distillate possesses the taste, aroma, and characteristics generally attributed to rum, and bottled at not less than 80 proof; and also includes mixtures solely of such distillates.' [10].

For the European Union, rum is defined as:

(1) 'a spirit drink produced exclusively by alcoholic fermentation and distillation, either from molasses or syrup produced in the manufacture of cane sugar or from sugarcane juice itself and distilled at less than $96 \%$ volume so that the distillate has the discernible specific organoleptic characteristics of rum.'

(2) 'a spirit drink produced exclusively by alcoholic fermentation and distillation of sugar-cane juice which has the aromatic characteristics specific to rum and a volatile substances content equal to or exceeding $225 \mathrm{~g}$ per hectolitre of $100 \%$ vol. alcohol. This spirit may be placed on the market with the word 'agricultural' qualifying the sales denomination 'rum' accompanied by any of the geographical indications of the French Overseas Departments and the Autonomous Region of Madeira as registered in Annex III.' [11]

In the Caribbean regions, rum is defined by the CARICOM regional standards as:

(1) 'a spirit obtained exclusively by alcoholic fermentation and distillation of sugar cane molasses, sugar cane syrups, sugar cane juices or cane sugar produced during the processing of sugar cane.'

(2) 'a spirit drink distilled at an alcohol content of less than $96.0 \%$ alcohol by volume at $20^{\circ} \mathrm{C}$.

(3) 'a spirit drink produced in such a way that the product has the organoleptic characteristics derived from the natural volatile elements contained in the above raw materials or formed during the fermentation or distillation process of the named raw materials; and which includes mixtures solely of the above distillate.' [12]

\subsection{Types of Rum}

In general, grades or styles of rum are classified by their origin, flavour, colour and taste. Numerous styles of rum have been developed around the globe, including white, dark, amber, over-proof and spiced rums (Table 1). Dark rum is aged for over two years in charred oak barrels and has a darker colour as it is not filtered following the aging process. Gold or 'amber' rum is also aged in charred oak barrels, albeit for a shorter period of time (18 months). Caramel may be added after the aging process to provide a more vivid golden colour and adjust the colour of the rum to a predetermined standard [13]. White rum (also known as 'silver', 'light' or 'clear' rum) is usually stored in stainless steel vessels or casks 
and aged for 1-2 years [6], with charcoal filters used to extract any colour and impurities after the ageing process. It has a lighter taste than amber and dark rum; hence is usually used in cocktails rather than being drunk neat. Over-proofed rums are the most popular rums on the Caribbean Islands market [1], with a higher alcohol content than the typical $37-40 \%$ alcohol by volume (ABV) $[8,14]$. These rums constitute almost $70-80 \% \mathrm{ABV}$ and are usually used for punching (creation of rum-based fruit cocktails). Spiced rums are infused during the blending stage with spices such as cinnamon, aniseed, ginger, rosemary or pepper at concentrations up to $2.5 \% w / v[12,13,15]$. Spiced rum is usually dark in colour, with sugar or caramel occasionally added for sweetness [16].

Table 1. A summary of the major types of rum and their properties.

\begin{tabular}{|c|c|c|c|c|}
\hline Rum Type & Aging & $\begin{array}{l}\text { Principal } \\
\text { Production } \\
\text { Region(s) }\end{array}$ & $\begin{array}{l}\text { Ethanol } \\
\text { Content } \\
(\% \mathrm{ABV})\end{array}$ & Additional Notes \\
\hline White & $\begin{array}{c}\text { Stainless steel casks } \\
\text { (1-2 yrs); often aged less } \\
\text { than other rums }\end{array}$ & Puerto Rico & $37-43$ & $\begin{array}{l}\text { Lighter bodied; filtered } \\
\text { before sale }\end{array}$ \\
\hline Dark & $\begin{array}{l}\text { Charred oak barrels } \\
\text { ( } 2 \text { yrs })\end{array}$ & $\begin{array}{c}\text { Jamaica, } \\
\text { La Martinica }\end{array}$ & $37-43$ & Darker, fuller flavour \\
\hline Amber/Gold & $\begin{array}{l}\text { Charred oak barrels } \\
\text { (1.5 yrs })\end{array}$ & $\begin{array}{c}\text { Cuba, } \\
\text { Puerto Rico }\end{array}$ & $37-43$ & $\begin{array}{c}\text { Flavour not as complex } \\
\text { as dark rums }\end{array}$ \\
\hline $\begin{array}{l}\text { Over proof/ } \\
\text { Naval }\end{array}$ & $\begin{array}{l}\text { Variable; can be sold with } \\
\text { no aging in some countries }\end{array}$ & Jamaica & $70-80$ & \\
\hline Spiced & $\begin{array}{l}\text { Charred oak barrels } \\
\qquad(1-2 \text { yrs })\end{array}$ & $\begin{array}{c}\text { Jamaica, } \\
\text { Puerto Rico }\end{array}$ & $37-43$ & $\begin{array}{l}\text { Most are darker in colour } \\
\text { and based on gold rums }\end{array}$ \\
\hline $\begin{array}{l}\text { Demerara } \\
\text { Rum }\end{array}$ & Longer aging & Guyana & $37-43$ & $\begin{array}{l}\text { Distilled in old stills; } \\
\text { complex } \\
\text { flavour similar to } \\
\text { Jamaican rum }\end{array}$ \\
\hline
\end{tabular}

\subsection{Global Rum Production Statistics}

Globally, the annual revenue from rum production amounts to an estimated USD 15.8 billion (in 2020), with a projected growth rate of $7.0 \%$ p.a. over the next five years (20202025), creating significant market opportunity [17]. Furthermore, there is increasing global demand for premium high-quality and luxury spirit products, with a focus on authenticity and well-known brands [18]. The USA is the largest consumer of rum [14] with USD 2435 million generated in revenue in 2020 [17], and sales volumes second only to vodka and whisky in the spirits category. Although China creates the largest amount of revenue from all distilled beverages (around USD 269 billion in 2020), the main producers of rum are countries from Latin America and the Caribbean region [17]. However, significant amounts of rum production also occur in other countries where sugar cane is cultivated as a primary industry, principally in the Philippines, India, Brazil, Fiji and Australia.

\subsection{Review Aim}

In the remainder of this review, we firstly discuss the production and composition of sugarcane molasses, the primary feedstock for rum production. We then continue on to discuss the process of rum fermentation and manufacturing, as well as the chemical composition of rum produced from molasses, including flavour-active compounds. Finally, we identify the contemporary challenges in the fermentation process and suggest potential solutions and directions where future research is required in view of optimising the whole rum production process.

\section{Molasses: The Feedstock for Rum Production}

\subsection{Production of Molasses}

Molasses is the one of the four main by-products of sugar processing of sugarcontaining crops, the others being tops, bagasse and filter muds. Sugar cane molasses is the 
primary feedstock used in the manufacture of rum [6]; hence we focus on this source in the present review. However, it is important to note that other feedstocks such as sugar cane juice or syrup may also be used for the production of rum, where permitted by law [11,12].

Sugar cane is a tall, tropical grass with stalks rising to 2-6 metres in height. When mature, the stems can contain around $15 \% w / v$ aqueous sugar solution in the form of sucrose; however, this depends on the sugar cane cultivar, farming methods and environmental factors (e.g., soil fertility, drought, pathogenic stresses, climate and rainfall). In remarkable cases, sucrose contents of up to $50-60 \% w / v$ have been reported [19].

Historically, it was common practice to burn the sugar cane crop fields just prior to manual harvesting (by machete or cane knives) to remove fibrous plant material, remediate hazards such as snake prevalence, and to reduce the mass of the harvested crop and thus transportation costs [20]. However, with the development of mechanical harvesting this practice is now far less frequent, with the cane typically harvested without burning in order to maximise sugar quality. Sugar cane juice is extracted from the harvested crop by crushing the stems and subsequent pressing to dry matter [6]. The resultant juice is boiled to reduce the water content to the desired consistency-as measured by its viscosity-leaving the first molasses concentrate after the initial boiling process. The second molasses concentrate is derived from re-boiling the first molasses, where the raw sugar starts to crystallise and to separate. Blackstrap molasses is the final molasses by-product that is formed from subsequent boiling and crystallisation-based extraction of the second molasses [4]. As a result of the additional steps involved in its processing, blackstrap molasses has a more pronounced, slightly bitter taste compared to the first and second molasses. Another type of molasses, refinery molasses, is created during the processing of raw sugar to white sugar, which releases molasses originally bound to the raw sugar crystals. Due to its abundance and comparatively low cost, blackstrap molasses is the most widely raw material medium utilised in the fermentation and production of rum [21]. However, some rum producers may also blend refinery-grade molasses with their blackstrap stocks.

Typically, distilleries will purchase and store as much molasses as possible during the cane crushing season, which is then used for the remainder of the year, until the next crushing season begins. This ensures that supplies of molasses are available to the distillery throughout the year, regardless of when the sugar cane crushing season has taken place. Rum producers typically have several storage facilities, used on a rotational basis to avoid the use of 'fresh' molasses and to avoid seasonal variations or periodic supplies [13]. Based on the experience of distilleries and the relevant literature, the best practice is to age molasses for a period of several months (typically a minimum of 6 weeks) prior to use [22], as shorter storage periods often result in incomplete fermentation, distillation difficulties and inferior final rum quality.

\subsection{Physical and Chemical Properties of Sugar Cane Molasses}

The composition and quality of molasses will in turn greatly influence the quality of the rum produced, as well as the efficiency and efficacy of the production process itself. Quality assurance testing of the key raw material (molasses) for its chemical, physical and microbiological properties is a mandatory requirement as part of the manufacture and production of rum. In terms of its physical properties, molasses is a dark brownish, viscous liquid with a $\mathrm{pH}$ of between 2.5-5.5 (typically $~ 4$ ), due to the presence of various organic acids (Table 2) [23]. It contains around 55\% w/v of total fermentable sugars, comprising 35\% sucrose and $20 \%$ glucose and fructose [15]. The total nitrogen content is another important nutrient, comprising the sum of all organic and inorganic nitrogenous compounds present. In molasses, the total nitrogen content comprises less than $2.0 \% w / v$ and can be further differentiated into free amino nitrogen (FAN) (ammonia and amino acids) $(0.2-0.45 \% w / v)$ and crude protein (approximately $0.5 \%$ w/v with respect to nitrogen content) [24]. Gums may comprise up to $6 \% w / v$, being represented by hemicelluloses, pectins and dextrins contained in sugar cane and levans that may be formed by bacteria during the sugar cane milling process $[25,26]$. In addition to these aforementioned compounds, molasses contains 
trace quantities of several other compounds, including minerals, nutrients and vitamins such as inositol and pantothenic acid (Table 2) [27].

Table 2. Typical physical and chemical composition of sugar cane molasses. Note that the data provided here are for molasses in general, not that specifically used in rum production.

\begin{tabular}{|c|c|c|}
\hline Constituents & Typical Range & References \\
\hline \multicolumn{3}{|c|}{ Physical Parameters } \\
\hline Moisture Content (\%) & $17-25$ & [28] \\
\hline $\mathrm{pH}$ & $2.5-5.5$ & {$[23,28,29]$} \\
\hline $\operatorname{Ash}(\% w / w)$ & $10-16$ & {$[28,30,31]$} \\
\hline Water activity $\left(\mathrm{A}_{\mathrm{w}}\right)$ & 0.76 & [32] \\
\hline $\begin{array}{l}\text { Total dissolved solids (TDS) (\% } \\
\qquad w / w)\end{array}$ & 76.6 & [28] \\
\hline${ }^{\circ}$ Brix & $79.5-89.5$ & [28] \\
\hline Volatile matter $(\%)$ & 86.3 & [33] \\
\hline Protein $(\%)$ & 0.145 & [33] \\
\hline Gums $(\% w / w)$ & 6 & {$[25,26]$} \\
\hline Colloidal substances $(\% w / w)$ & 9.2 & [34] \\
\hline \multicolumn{3}{|c|}{ Sugars $(\% w / w)$} \\
\hline Sucrose & $30-57$ & {$[15,28]$} \\
\hline Fructose & $5-13$ & [28] \\
\hline Glucose & $4-10$ & [28] \\
\hline Maltose & 0.11 & [28] \\
\hline Maltotriose & 0.43 & [28] \\
\hline Isomaltose & 0.020 & [28] \\
\hline Non-fermentable sugars $(\% w / w)$ & 5.1 & [34] \\
\hline Total fermentable sugars $(\% w / w)$ & 54 & [34] \\
\hline \multicolumn{3}{|c|}{ Nitrogenous substances $(\% w / w)$} \\
\hline Total nitrogen & $0.36-1.97$ & {$[24,28]$} \\
\hline Free amino nitrogen (FAN) & 0.10 & {$[28]$} \\
\hline \multicolumn{3}{|c|}{ Minerals $\left(\mathrm{mg} \mathrm{L}^{-1}\right)$} \\
\hline Sodium & 1600 & [28] \\
\hline Phosphorus & 600 & [28] \\
\hline Potassium & 27200 & [28] \\
\hline Sulphur & 3800 & [28] \\
\hline Calcium & 10600 & [28] \\
\hline Magnesium & 4200 & [28] \\
\hline Copper & 17 & [28] \\
\hline Iron & $150-1170$ & {$[28,30]$} \\
\hline Manganese & 53 & [28] \\
\hline Zinc & 19 & [28] \\
\hline
\end{tabular}


Table 2. Cont.

\begin{tabular}{ccc}
\hline Constituents & Typical Range & References \\
\hline Thiamin (B1) & Vitamins $\left(\mathrm{mg} \mathrm{L}^{-1}\right)$ & \\
\hline Riboflavin (B2) & $2-10$ & {$[35]$} \\
\hline Pyridoxine (B6) & $1-6$ & {$[35]$} \\
\hline Nicotinamide & $1-10$ & {$[35]$} \\
\hline Pantothenic acid & $1-25$ & {$[35]$} \\
\hline Folic acid & $2-25$ & {$[35]$} \\
\hline Biotin & $10-50$ & {$[35]$} \\
\hline Organic acids (\% $w / w)$ & $0.1-2$ & {$[36]$} \\
\hline Acetic acid & & {$[36,37]$} \\
\hline Aconitic acid & $0.2-1$ & {$[36,38]$} \\
\hline Formic acid & $0.05-0.8$ & {$[39]$} \\
\hline Valeric acid & $0.097-0.12$ & {$[36]$} \\
\hline Lactic acid & $<0.1$ & {$[36]$} \\
\hline Citric acid & $\sim 0.05$ & {$[37]$} \\
\hline Malic acid & $\sim 0.05$ & \\
\hline
\end{tabular}

$\mathrm{ND}=$ no data

Traditionally, distillers have used ${ }^{\circ}$ Brix, the percentage sugar content of an aqueous solution, as an indicator of the fermentable sugar content of molasses. Molasses with a ${ }^{\circ}$ Brix of 87.6 have been recommended for the production of high-quality rum with desirable flavours and the greatest ethanol yield (theoretical yield of $\sim 40 \%$ ethanol $w / w)[31,40]$. Poor quality rums are obtained from molasses with ${ }^{\circ}$ Brix less than 85.4 or ${ }^{\circ}$ Brix greater than 88.2, due to these providing inadequate energy for yeast growth or inhibiting yeast growth, respectively [40]. Knowledge of the quantities of fermentable sugars allows distillers to predict the theoretical yield of ethanol more accurately from a given batch of molasses. In order to achieve efficient fermentation with optimum ethanol yield and produce rum with a consistent and desirable organoleptic profile, the selection of suitably high-quality molasses for fermentation processes cannot be overemphasised [41,42].

Molasses typically contains adequate levels of carbon and other micronutrients, such as minerals and vitamins, to allow for microbial growth. However, it has a very high concentration of soluble sugar, low water activity, relatively low $\mathrm{pH}$ and is a poor source of nitrogen and phosphorus (Table 1) [28,34]. As a result, this creates an unfavourable and extremely stressful environment for microbial growth and survival, with only a few well-adapted species such as Bacillus subtilis and Schizosaccharomyces pombe able to survive these conditions $[23,27]$. Furthermore, undue stress on the yeast cells can contribute to the formation of undesirable flavour compounds thus impacting on the desired consistency of organoleptic profile of the rum produced. This situation can be remedied to some extent by diluting molasses with water which will reduce the stress of high sugar content and low water activity. For the production of rum, molasses is normally diluted to around 15-20 ${ }^{\circ}$ Brix or $10-15 \% w / v$ fermentable sugars [6] prior to inoculation with the commonly used species of distiller's yeast, Saccharomyces cerevisiae. However, dilution does not solve all of the aforementioned problems-including the lack of nitrogen and phosphorus. If these nutrients are not present in adequate concentrations, the fermentation process begins to slow down due to inhibited growth of the yeast, giving a condition known as "stuck fermentation". This has significant negative impacts on rum consistency and production efficiency [43]. To remedy nitrogen and/or phosphate deficiencies, rum producers occasionally supplement the diluted molasses medium with ammonium phosphate or ammonium 
sulphate at levels between $0.03-0.06 \%$ [44,45]. However, it is equally important to carefully monitor the addition of these supplements, as excess nitrogen in the medium can inhibit the growth of yeast and affect the development of flavour metabolites [41].

Furthermore, molasses may contain a variety of other chemical compounds not mentioned thus far that have the potential to inhibit yeast growth if they are present in high concentrations. One such compound is hydroxymethyl furfural (HMF), which is formed when cane molasses is overheated during sugar processing at a low $\mathrm{pH}$ level (e.g., $\mathrm{pH}$ <4) [46]. Although HMF levels up to $0.4 \% w / v$ can be tolerated by yeasts, effort should be made to make sure that concentrations higher than this is prevented [47]. A number of low molecular weight organic acids can be found in molasses, the most prevalent of which are acetic, malic, lactic and citric acids (Table 2). Some of these organic acids-most notably acetic, butyric and valeric acid - can have inhibitory effects on the growth of yeast when present at higher concentrations [48,49]. It is therefore necessary to prepare and store molasses under conditions that prevent the formation of these inhibitors.

\subsection{Impact of Sugarcane Cultivation on Molasses Quality}

Both the quality of sugarcane juice and molasses are affected by several factors, such as the nutrients and topology of the soil, variety of sugarcane, climate and harvesting [50] In addition, many agronomic factors during the production of sugar cane can influence the resultant composition and consistency of the ensuing molasses following sugar cane processing as well. These include conditions such as soil type, ambient temperature, moisture, growing season, sugar cane cultivar and cultivation practices, as well as the specific sugar refining processes and storage conditions for the molasses [51]. This can produce significant differences in nutrient content, taste, colour, viscosity and total sugar content of the resultant product. For example, elevated soil salinity is known to reduce the juice quality (e.g., sugar content, minerals) in sugarcane [52]. Similarly, changes in atmospheric conditions can affect plant biomass which in turn influences cane and juice quality and sugar recovery [53]. Interestingly, it has recently been reported that while agriculturally relevant variables such as soil moisture tension do not significantly affect the quality of sugar cane juice, the Brix degrees and sucrose content may be affected [54].

\section{Rum Production Processes}

The basic method for the production of rum comprises the following operations: preparation of the molasses; fermentation of the raw material; distillation of the fermented product; collection of the distillate; maturation of the distillate in wooden barrels; and packaging of the final product [55]. These steps are presented graphically in Figure 1 and discussed in more detail in the following sections.

\subsection{Pre-Treatment of Molasses}

Immediately prior to use in the fermentation process, the molasses feedstock is clarified to remove the majority of suspended solids present. Although this is normally achieved through the use of chemical flocculating agents, centrifugation can also be utilised. The $\mathrm{pH}$ is subsequently adjusted to around 5.0-5.5 using sulphuric acid, followed by mild heat pasteurization $\left(80^{\circ} \mathrm{C}\right)$. This removes colloidal material from the molasses, preventing it from fouling the distillation columns or causing inefficiency of the stills $[3,56]$. The period of pasteurization, whilst frequently unrecorded, is usually between $15-25 \mathrm{~s}$ but can vary considerably from one distillery to another.

After gravity settling or centrifugation to remove solid particulates, the clarified molasses is diluted with potable water to achieve a final concentration of $10-15 \%$ w/v fermentable sugars (15-20 ${ }^{\circ}$ Brix) [6]. However, dilution will lower the concentration of sugars and consequently result in a lower yield of alcohol after fermentation. Distilleries circumvent this by incrementally feeding molasses (at $40{ }^{\circ}$ Brix) into the fermentation mixture over a period of several hours after the sugar content has dropped to $15^{\circ}$ Brix. This will elevate the concentration to about $20^{\circ}$ Brix, allowing for a rapid and efficient 
fermentation $[3,13]$. Yeast nutrients such as ammonium sulphate and vitamins can be added at this time to ensure all key nutrients are present in adequate amounts for full fermentation to occur [6]. At this point, dunder-the volatile-depleted, liquid residue remaining in the stills after previous batches of rum fermentation-is also added to the molasses [57]. The resultant mixture is then cooled to around $30{ }^{\circ} \mathrm{C}$ by heat exchange and pumped into large fermentation vessels.

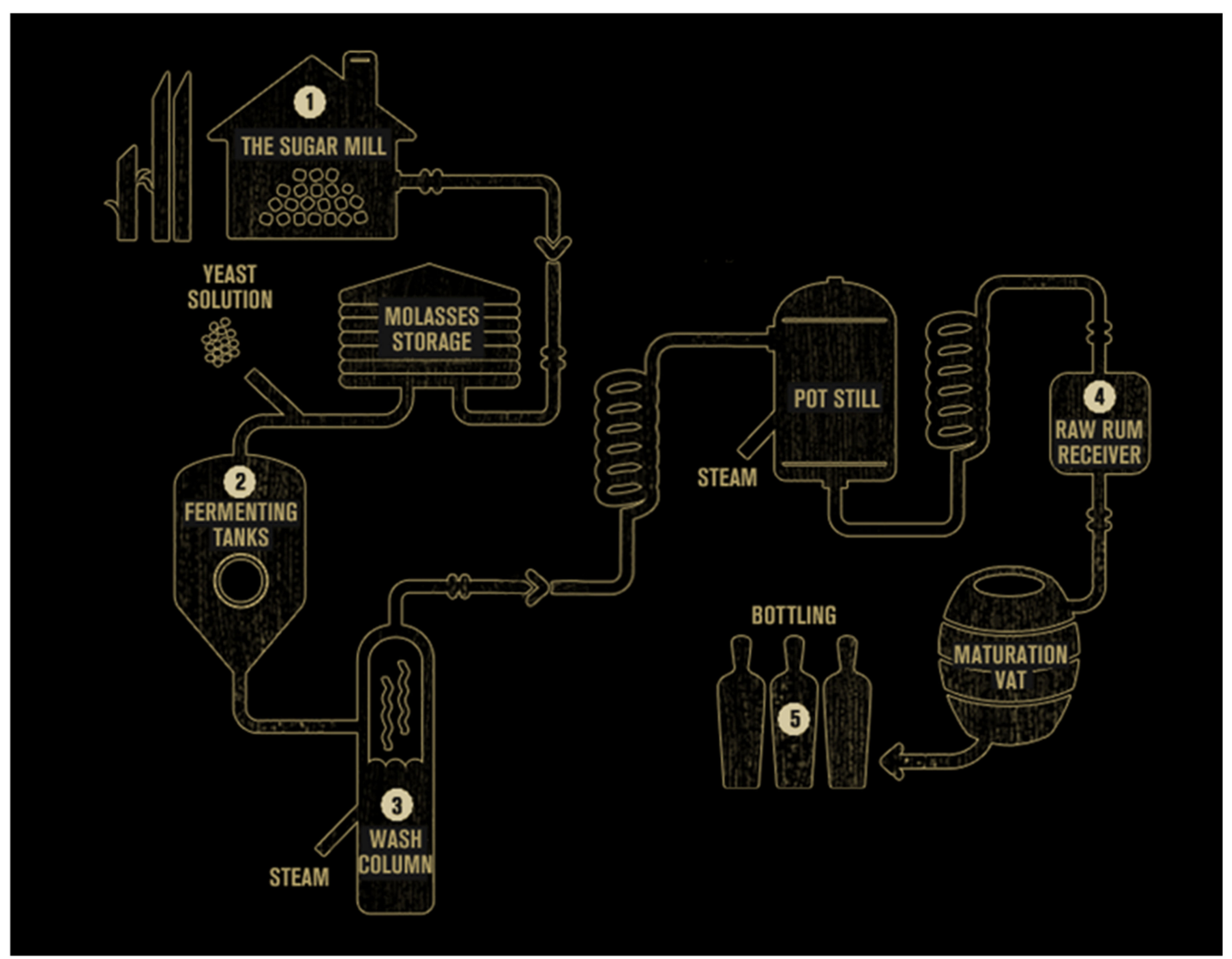

Figure 1. A general overview of the rum production process. Modified from Bundaberg Rum (https://www.bundabergrum. com.au/ (accessed on 8 February 2021)); used with permission.

\subsection{Yeast Propagation}

Modern rum distilleries initiate the process of fermentation through inoculation with starter cultures of selected yeast strains, most commonly Saccharomyces cerevisiae. These strains are often maintained as pure 'in-house' cultures and propagated to inoculum volumes on site. Over time, this can result in individualised yeast strains, which may contribute to the specific organoleptic profiles of different manufacturers' products. Other distillers may purchase yeast as dried cultures from specialized companies and rehydrate them prior to propagation and use for inoculation. There are four methods of propagation that are commonly used in the fermentation industry: continuous, semicontinuous, multiple batch and single batch [6], depending on the facilities and requirements of the distillery.

The first step in the inoculation process is to validate the purity of the yeast culture (whether in-house or purchased) through agar plating. From this culture, a small volume (100-500 mL) of liquid culture is aseptically prepared and used to inoculate around fifty litres of sterile (autoclaved) medium.

The inoculated medium is subsequently incubated with aeration to increase the number of viable cells before being aseptically transferred to a larger volume (500 L). The propagation medium is formulated to have a similar composition to the molasses fermentation medium (aside from additional yeast nutrients) to ensure that the yeast is 
well adapted to the fermentation conditions. The transfer of culture to increasingly larger volumes is carried out to obtain a volume of yeast inoculum approximately $10-30 \%$ of the intended final molasses fermentation volume, with a starting yeast population of approximately $10^{6}$ cells $/ \mathrm{mL}$ [56]. The final stages of propagation typically involve large quantities of non-autoclaved molasses diluted to around $10-15 \%$ fermentable sugars similar to the final fermentation medium [6].

Temperature has a large impact on propagation efficiency; hence it is routinely monitored and regulated. The optimum temperature depends on the specific strain of yeast but is normally at least $2-5{ }^{\circ} \mathrm{C}$ below normal fermentation temperatures (which typically range between $28-35^{\circ} \mathrm{C}$ ). When the yeast reaches the most active stage of growth (log phase), it is moved from the propagator to the batch fermenter.

Throughout propagation, quality control measures are used to ensure cell viability and the purity of the culture. The viability of yeast cells can be easily determined using methylene blue (or other cellular stains) to distinguish between viable and non-viable cells. When used in conjunction with cell counts using a haemocytometer, this provides a fast approximation of the number of viable cells, compared to the much slower culture plating methods. Culture purity can also be easily determined by microscopy or through real-time Polymerase Chain Reaction (PCR) [58].

\subsection{Rum Fermentation Processes}

Yeasts control the alcoholic fermentation of fermentable sugars in molasses, metabolising them primarily into ethanol and carbon dioxide, as well as trace quantities of a broad variety of secondary metabolites. In some instances, bacterial strains may also significantly influence the fermentation process $[45,59]$. The bacterial species occur as indigenous contaminants within the processing environment, predominantly originating from sugar cane stalks via the molasses feedstock. Some bacterial contaminants may also arise in sites that escaped effective cleaning and sanitation operations. In rum production media, the most significant bacterial contaminants are typically Lactobacillus sp. and Propionibacterium sp. [45,59]. If present at excessive concentrations, these species can inhibit the fermentation process and produce unwanted metabolites (e.g., propenal, acrylate). However, the complete eradication of these bacterial species may not be desirable, as they produce important flavour-active compounds (e.g., 2,3-butanediol, diacetyl, propionic acid) responsible for imparting some of the characteristic flavour of rum [59,60].

Most rum fermentations are carried out in large (up to 100,000 L) closed stainless steel "cyclindro-conical" vessels, fitted with stirring and sparging devices, temperature control, and cleaning in place (CIP) facilities $[61,62]$. The fermentation mixture can be gently stirred to maintain the yeast cells in suspension and ensuring they can assimilate the available nutrients. Rum fermentations can vary in duration from $20 \mathrm{~h}$ to 21 days [15], with many distilleries running fermentations for standardised lengths of time to produce a given rum product. Longer fermentations ( $>7$ days) result in heavier flavoured rums such as those typically used in cooking and confectionary [14], while shorter fermentations $(20-26 \mathrm{~h})$ are used to produce lighter rums [15]. Fermentations are usually performed at a temperature of $28-35^{\circ} \mathrm{C}$ to optimise the rate of yeast growth and hence completion rate of the fermentation. As the fermentation process is exothermic and thus generates heat, fermenters are cooled to ensure that the temperature does not exceed $37^{\circ} \mathrm{C}$ and result in loss of yeast viability. If this happens, the fermentation process will cease and remain incomplete or "stuck", leading to major process inefficiencies. Cooling can be provided in the form of internal cooling coils or plates linked to cooling towers, double-jacketed walls with cooling in the outer walls, recirculating spirals, plate and frame or shell in tube heat exchangers [61].

In a well-run fermentation, most of the sugars are converted into ethanol; a small percentage is converted into other by-products including glycerol, organic acids and certain flavour compounds $[63,64]$. The end point of the fermentation is achieved upon reaching the desired alcohol content (usually between $5-7 \%$ ) or the complete consumption of the 
sugar content. Depending on the analytical equipment available, the distillery may use alcohol content, final gravity or ${ }^{\circ}$ Brix to monitor the fermentation process and assess its completion.

\subsection{Distillation}

Distillation is a crucial step in the rum manufacturing process, as it separates and concentrates the volatile components of the fermented molasses mixture [44]. The volatile fraction of the fermented molasses mixture consists primarily of ethanol and lower concentrations of carbon bearing alkanols, organic acids, esters, phenols and other carbonyl and nitrogen-containing compounds (Supplementary Materials, Table S1). The collective term "congeners" has been used to describe all volatile components in the distillate obtained from the fermented molasses mixture, aside from ethanol [56]. These congeners are the principal contributors to the unique and distinctive organoleptic properties of rum.

Distillation serves to concentrate the ethanol produced and refine the organoleptic properties of the final product, by selecting for the types and concentrations of desired volatile compounds formed during the fermentation process, based on their boiling points. In addition, distillation can create new compounds through esterification and dehydration reactions between these components. For example, pot distillation has been found to increase concentrations of furfural, a furan with almond-like sensory characters [65]. While the technology for commercial distillation of alcoholic drinks, including rum, varies with specific producers, the general principles of the process remain the same and are outlined here $[62,66]$.

The fractional distillation process takes advantage of the difference in the boiling points of ethanol, water and other constituents, resulting from their different chemical properties. Fractional distillation can be achieved using either a stationary column still, or by increasing the temperature of the still over time. In the former case, the most volatile compounds (e.g., acetaldehyde, acetone, methanol, ethyl acetate) are collected from the top of the still, ethanol and other moderately volatile from the centre, and non-volatile compounds from the base. In the latter case, different compounds emerge over time, depending on their boiling point.

Distillers can distinguish their own 'cuts', i.e., time-based fractions of the distillate, based on the relative volatility of the compounds emerging at different time points. The "head" cut is the first distillate fraction to emerge, comprising compounds with a low boiling point and harsh solvent-like aromas, including acetaldehyde (boiling point of $\left.20{ }^{\circ} \mathrm{C}\right)$, acetone $\left(56^{\circ} \mathrm{C}\right)$ and methanol $\left(65^{\circ} \mathrm{C}\right)$. The removal of methanol is particularly important, as it can acute toxicity via hypoxia and metabolic acidosis if ingested [67].

The subsequent cut is the "heart", which comprises a mixture of more complex volatiles, alongside ethanol (boiling point of approximately $78^{\circ} \mathrm{C}$, depending on the matrix complexity) [68]. This cut-also referred to as the "raw" or "unaged" rum-is of the greatest commercial importance, containing most of the desired congeners (e.g., ethyl butanoate, ethyl acetate, isobutyl alcohol, 2,3-butanedione, $\beta$-damascenone) [29]. Condensation of the heart cut produces a spirit distillate comprising 60-94\% ABV, depending on the type of distillation unit used. Some undesirable compounds can also occur in the heart portion, such as isoamyl alcohol (bp $132^{\circ} \mathrm{C}$ ), which imparts bitterness and a sharp odour to the rum. The heart cut may be collected as several fractions, which highly skilled distillers can combine to produce a final rum product with the same consistency as that from previous fermentation batches.

The "tail" cuts emerging later in the distillation process are also undesired, as they predominantly comprise low molecular weight organic acids with pungent or rancid odours (e.g., 2- and 3-methyl butanoic acid, propionic acid, butyric acid) [69]. As previously mentioned, distilleries can also use stationary column stills, in which case the heads are continuously collected from the top of the still; the heart from the centre of the still; and tails from the base of the still. 
There are two types of distillation processes that can be used for the production of rum: batch distillation and continuous distillation. Batch distillation utilises pot stills and is used to produce rums with stronger, heavier flavours, such as those characteristics of Barbados, Bermuda, Jamaica and other English-speaking regions of the Caribbean. Continuous distillation uses column stills and is used in the manufacture of lighter-style rums such as those from the former Spanish colonies (e.g., Cuba, Panama). However, some distilleries use a combination of both methods $[39,70]$.

\subsection{Post-Fermentation Processes: Maturation and Aging}

It is a common misconception to interchangeably use the terms "maturation" and "ageing". Whilst maturation is the final stage achieved after aging, a mature rum is not defined by having spent a fixed period of time in a barrel. Instead, the maturity of the rum is assessed by its distinctive characteristics, including the body, colour, aroma and taste acquired during aging. In contrast, aging is defined as the literal period of time that the rum is stored in a wooden barrel [6].

The rum industry uses two types of wooden barrels in the aging processes: new barrels and second-hand barrels previously used for maturation of other alcoholic beveragespredominantly whisky, but also occasionally those used for wine and brandy. The main reason for using pre-used whisky barrels is the cheaper price, in addition to the fact that these used barrels have previously been 'cured' or charred. If using new barrels, these must be heated or charred (burning the inside surface of the barrel) prior to processing the raw spirit. The charring process alters the physical and chemical composition of wood by caramelising sugars, increasing vanillin content and removing undesired tannins $[61,71,72]$. Whilst many specific types of wood may be used for the construction of barrels (including acacia, chestnut, mulberry and cherry) [73,74], the American oak (Quercus alba) is the most commonly used due to its characteristic organoleptic profile. Specific flavour-active compounds, including vanillin (providing a vanilla-like flavour), cis and trans-whisky lactone (coconut flavour) and eugenol (spicy clove-like flavour), are known to be produced by oak wood $[55,72,75]$. The production of cask/barrels is not standardised, with large differences observable between cooperages of different countries [76,77].

Despite the important characteristics that barrels impart on the eventual organoleptic properties of rum during the aging process, distillers have little influence over the factors influencing barrel quality. The most important of these factors include the tree species, soil and environmental conditions, age of the tree at time of harvest, the manner in which they were cut, the part of the tree from which the staves were derived, the variety and quantity of resins present, and the length of time for which boards were aged prior to barrel construction [71].

Within the closed confinement of the wooden barrel, a complex array of physical and chemical interactions take place during maturation between the wood barrel, the ambient environment and the maturing spirit mixture, including: (i) direct extraction of chemical constituents (e.g., phenols, benzoic acid, tannins) from the wood, (ii) decomposition of the wood (usually oak but other woods like maple, cherry and hickory can be used) on a molecular level and interaction of the resulting compounds with the distillate, (iii) reactions between the components extracted from the wood and those already present in the rum distillate, (iv) reaction between wood compounds within the raw rum, (v) reactions between raw rum compounds, (vi) evaporation of volatile compounds through the cask, and (vii) interaction between the raw spirit and air present in the headspace of the cask or vat [72]. These interactions transform the taste, colour and composition of the resultant alcoholic beverage. Distillates collected straight from the still are clear in appearance, but the rum-wood interactions during maturation bestow the finished rum product with its yellow/golden colour, depending on the aging period. The effects and time needed for maturation are variable and are affected by a broad range of factors including atmospheric conditions, type and location of warehouse. However, the type of barrel used is the most important factor [6]. 
The amount of time required to age raw rum depends on the type of rum being produced as well as the target market. White rums are not usually aged for prolonged periods, except where a minimum aging period is required by law. These rums are usually aged in stainless steel casks (where permitted by relevant legislation) or old, well-used barrels, followed by charcoal filtration to remove any colour prior to bottling. Amber and dark rums can be aged anywhere between 12 months and 25 years. Typically, the longer the rum spends in the oak barrel, the darker the rum and the more complex its flavour overtones [61,62]. Many countries have laws regulating the minimum length of time that a product must be aged before it can be advertised and sold as "rum". For example, to be sold in Australia, the Dominican Republic and Panama, rum must be aged for at least 2 years [9]. Mexico's law requires a shorter length of time, with a minimum of 8 months.

\section{Composition of Rum}

\subsection{General Composition}

The distinctive features of rum-and indeed its main consumer preference criteriaare attributed to its organoleptic properties. These perceived sensory characteristics are determined by the identities and absolute quantities of volatile organic compounds present in the distillate collected from molasses fermentation. In terms of absolute composition, the key component of rum is ethanol. During a typical fermentation process, ethanol concentrations can reach a maximum of $6-8 \% v / v$, whilst levels of $10-13 \% v / v$ can be achieved using high gravity fermentation processes [3,6,35]. However, after distillation and bottling, the concentration of ethanol in the final rum product can range from $37-80 \% v / v$, depending on the brand of rum [6]. The remaining components are congeners (minor chemical constituents), of which around 100 have been identified (Supplementary Materials, Table S1). These organic compounds are by-products resulting from the metabolism of molasses by microorganisms (primarily Saccharomyces sp.) and the subsequent biochemical transformations that occur throughout the maturation timespan. Other microorganisms that may be present in minor concentrations and hence contribute to the volatile constituents include yeasts from the genera Candida, Debaryomyces, Schizosaccharomyces, Kluyveromyces, Pichia and Hanseniaspora, as well as the bacterial species Clostridium saccharobutyricum, Propionibacterium jensenii and lactic acid bacteria [45,59].

\subsection{Flavour-Active Compounds}

Although flavour-active compounds can possess a wide array of chemical properties, one of the most important groups of these compounds are characterised by their relatively low boiling points; hence are termed "volatile" compounds. These play a particularly important role in determining the perceived flavour of rum [78]. The profile of the volatile organoleptic compounds, which distinguishes rum from other distilled alcoholic beverages (such as whisky), is produced by the growing microorganisms as by-product during the fermentation of the molasses. The volatile compounds that have been identified and quantified in rum are provided in Table S1 of the Supplementary Materials, with eight of the major compounds shown in Figure 2. These volatile compounds are produced defined by the microbiology of the fermentation process and the distillation process, as well as the aging process [29]. The major compounds that have been found to increase during the aging of rum are vanillin (176-fold increase), 4-ethylphenol (72-fold), 3-hydroxy-4,5dimethylfuran-2-(5H)-one (49-fold) and 4-methylphenol (14-fold) [55].

There are significant differences in concentrations of odour-active compounds between different types of rums. One study identified the major odour active compounds in two different varieties of rum as ethanol, vanillin, ethyl (S)-2-methylbutanoate, $(E)-\beta$ damascenone, 2,3-butanedione, 3-methylbutanal and ethyl butanoate [79]. The most significant differences in concentrations between the two rum types were found for vanillin, cis-whiskey lactone, 4-allyl-2-methoxyphenol, 3-methylbutanal, 2,3-butanedione and ethyl butanoate. Notably, the authors of this study were able to simulate the odour of both rum samples by combining synthetic standards of all aroma-active compounds (i.e., those 
possessing odour activity values above 1) in the relative concentrations that they were present in the rum samples [79], indicating that nearly all of the important aroma-active constituents had been identified.

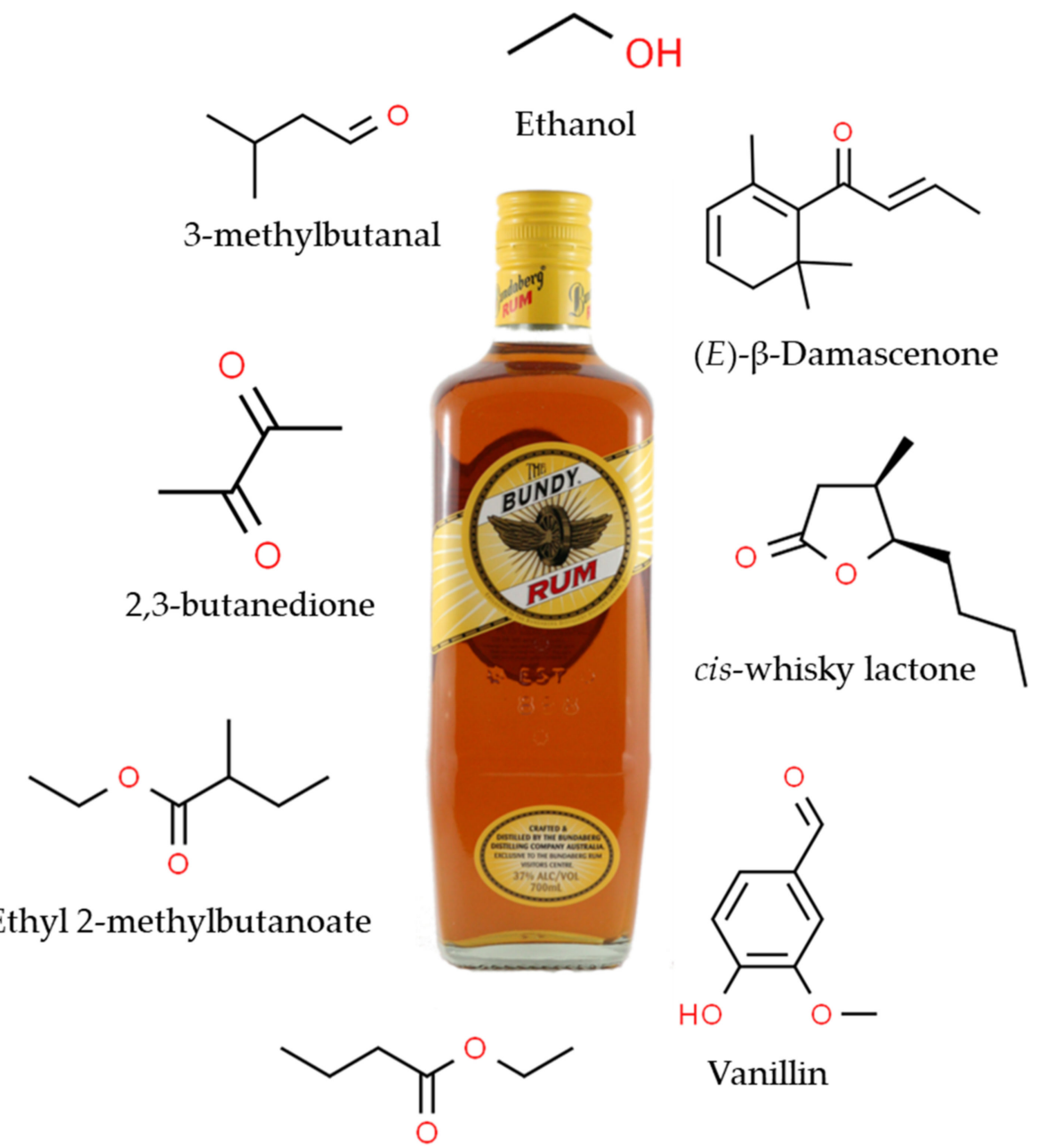

Ethyl butanoate

Figure 2. Some of the major flavour-active volatile compounds identified in rum.

\subsection{Other Constituents}

Herranz, et al. [80] analysed the concentrations of selected free fatty acids (octanoic and decanoic acids) as well as other major congeners (ethyl hexanoate, ethyl octanoate, ethyl decanoate and ethyl dodecanoate) in 57 samples of bottled rum from Spain. Octanoic and decanoic acids were found in concentrations between $0.5-14 \mathrm{mg} \mathrm{L}^{-1}$, while the high molecular weight esters were found at concentrations between $0.1-4.6 \mathrm{mg} \mathrm{L}^{-1}$.

Compared to other alcoholic beverages such as whisky, brandy and cognac, rum contains more volatile fatty acids overall, with particularly high levels of propionic and butyric acids [81]. Higher weight fatty acids such as caproic, capric and lauric acids were also found in appreciable levels ( $>5 \%$ of the total fatty acid content), with esters of these compounds commonly occurring [81].

\section{Quality Management in Rum Production}

As a finished product, rum must meet the consumer acceptance criteria based on parameters such as appearance, flavour and aroma characteristics. Rum should also comply with any technical and legal specifications, including aging periods and ethanol content. In addition to these, there should be consistency in the quality and organoleptic properties of 
the rum from batch to batch, which entails ensuring minimal variance in the production process over time. The fundamental concepts of good manufacturing practice and quality assurance and control, as applicable to food and beverage in general, should also apply to the rum industry [82].

As far as rum is concerned, Nicol [6] described specific operations in the process where quality control is particularly important. These include the quality of molasses obtained from the supplier; how the molasses is stored and prepared prior to fermentation; the preparation of inoculum cultures for fermentation; control of the fermentation and distillation processes; management of rum aging and maturation; analysis of product pre-, during and post- packaging; and the application of effective cleaning and sanitation throughout the production process.

It is important to define and establish clear management criteria for each of these phases in the rum production chain. This could entail, for example, the establishment of specifications for all raw materials, the identification of any hazards in the manufacturing chain that could affect quality, the identification of critical control points and control limits, the outline of cleaning and sanitation procedures, and the systematic documentation of management plans. The Hazard Analysis and Critical Control Points (HACCP) protocol, a mainstay of the food industry, has been used in larger distilleries for some time and is now a standard feature across many quality assurance programs [83]. The start of any HACCP program is a flow diagram of the entire production process; hence is unique to the needs of individual distilleries. Once the safety and quality hazards have been identified and analysed, critical control points are identified, and suitable instrumentation selected and installed.

However, HACCP is not a stand-alone program and must be combined with Good Manufacturing Practices (GMP), Standard Operating Procedures (SOPs) and other protocols to develop a robust quality assurance program. Overall, the goal of these programs is to is to identify the common critical control points in the distillery and to demonstrate how integrated process control and laboratory monitoring are used to ensure customer and product safety and maintain a high level of product quality while concomitantly streamlining production processes.

Traditionally, periodic visual inspection and random sample testing were the benchmarks against which all other measurements were assessed in distilleries, also forming the basis of additional safety and quality tests are built. These methods remain an integral part of quality control; however, are not as suited to monitoring real-time production as they offer only a snapshot of the entire rum production process. In-line process instrumentation enables continuous, live monitoring of process parameters, augments laboratory testing results, and assists in achieving process control and several HACCP principles in a single step. Following installation of the instrumentation, the remaining HACCP principles are straightforward and logical to apply; namely the establishment of critical limits and alarm limits; monitoring of critical control points; adjustment of process parameters when required; establishing corrective action to eliminate production errors at control points and following up when necessary; keeping adequate formal records to monitor quality and production trends; verifying that all quality criteria are met; and reviewing results to optimise quality and production [83].

Organoleptic assessments also play an important role in quality management. Rum composition is known to undergo changes throughout storage periods, altering the quality and taste of the product. A method of organoleptic assessment of rum is therefore necessary to complement other aspects of the quality assurance and quality control programs. Various distilleries have developed internal organoleptic testing sensory panels to ensure brand identity, predict consumer reaction to the product and improve rum quality accordingly. The process is developed and standardised against various other parameters for consistency and quality to ensure that objective assessments can be made. This also makes it easier to identify defective aspects and take adequate corrective actions to rectify the problem. 


\section{Current Challenges in the Fermentation Process-Globally \\ 6.1. Feedstock Variation}

Molasses has been described as a solution containing both sugar and nonsugar components, where the fermentable carbohydrates in turn typically have relatively high concentrations of calcium, potassium, and sulphur [84]. Deseo, et al. [85] describe molasses is known to be a rich source of polyphenols but it undergoes several processing steps in sugar cane milling, making its composition highly variable. This further means that its composition as a feedstock can be quite complex and unknown. The variability of the molasses feedstock is one of the major challenges that rum brewers face. It occurs as a result of several different factors, including feedstock types and environmental factors, harvesting practices, storage conditions and pre-processing techniques. In molasses intended for fermenting purposes, some of these factors can be controlled by standardization practices, while other factors can be more difficult to regulate. A recent publication has also noted that molasses has yet to be properly characterised, and that its description has mostly been limited to either the type of the origin sugarcane or beet, the amount of dry matter, total or water-soluble sugars, crude protein, and ash [86]. This means that a multivariate pool, including environmental factors affects the chemical composition of molasses. It may also be particularly difficult to control, given that sugar cane can be subject to variations in weather conditions, including total water supply and timing, daily and seasonal temperature changes and variations in local soil conditions.

\subsection{Incomplete Fermentation}

Incomplete or stuck fermentation occurs where the yeast used becomes dormant before fermentation is completed. Stuck fermentation is an unintentional and undesirable phenomenon, with the reduced growth rate of yeast allowing slower growing bacterial species to contaminate the rum. There are many possible causes of stuck fermentation-the most common being high temperatures that kill off the yeast, or a deficiency of nitrogen or other nutrients in the feedstock. When fermentation is halted, it is very difficult to restart as a consequence of compounds released by dying yeast cells, which inhibit the growth of yeast cells in the batch even if the original source of stuck fermentation is rectified [63].

There are a number of methods that distillers may use to reduce the chances of stuck fermentation occurring. The most popular is the use of cultured yeast strains with high alcohol and high temperature tolerance, combined with diligent control of fermentation temperature. Monitoring of nutrient levels and supplementation where required also plays an important role.

\subsection{Yeast Strains and Health}

The term "yeast" is often used synonymously with Saccharomyces cerevisiae (brewer's yeast) as this is the species most commonly used for fermentation purposes, including rum production. It requires a minimum water activity of 0.65 for growth; thus, requires environmental conditions with high water availability to thrive. Media containing excessive sugar concentrations can impose osmotic stress on the cells (due to reduced water availability), adversely affecting cell physiology. Under such conditions, yeast cells are likely to respond by overproducing glycerol or other osmolytes such as trehalose, which act to protect yeast membranes from desiccation. Needless to mention, overproduction of other metabolites such as glycerol detract significantly from the ethanol yield from fermentation. Regarding temperature and $\mathrm{pH}$ requirements for alcoholic fermentations, yeasts thrive in warm and acidic environments with most $S$. cerevisiae strains growing well between $20-30^{\circ} \mathrm{C}$ and $\mathrm{pH}$ 4.5-6.5. Commercial distilling yeast strains can ferment well at $32-35^{\circ} \mathrm{C}$, with metabolic activity declining rapidly above this temperature [45]. It must be noted that the optimum is conditions for growth are species and even strain specific. Each distillery maintains specific fermentation conditions and thus selects and maintains a strain that can function optimally under these conditions. This information usually forms part of the distillery's trade secrets, 
as the specific strain and growth conditions influence the flavour compounds produced and hence the brand identity.

In terms of the chemical composition of the wort, it is not solely the fermentable sugars that impact on yeast fermentation performance. The nutrient composition of the fermentation medium is vital for yeast growth and metabolism and hence the quality of the final rum produced. In order to efficiently carry out fermentation, yeasts require appropriate supplies of macronutrients, including sources of carbon (sugars), free amino nitrogen (amino acids, small peptides and ammonium salts), oxygen, sulphur, phosphorus, potassium and magnesium. Nitrogen utilisation during fermentation is important for the yeast protein formation (structural and enzymic) required for their growth [87] and other functions such as osmoregulation [88]. Moreover, the level and composition of molasses free amino nitrogen (FAN) also has a significant impact on higher alcohol, ester, vicinal diketone (VDK) and $\mathrm{H}_{2} \mathrm{~S}$ formation, due to the role of amino acid metabolism in the formation of these flavour compounds $[87,89]$. Conditions that stimulate fast yeast growth (high temperature and high DO concentrations) will lead to high FAN utilization, resulting in flavour imbalances.

In addition, yeast also require a number of micronutrients, primarily trace elements such as calcium, copper, iron, manganese and zinc [45]. Whilst the exact function of calcium is still debatable, its uptake in yeast suggests its multifunctional role as a second messenger in the modulation of growth and metabolic responses of cells to external stimuli and flocculation. Copper and iron, on the other hand, act as cofactors in several enzymes, including the redox pigments of the respiratory chain. Iron plays a key role in haeme formation and is further implicated in cellular redox homeostasis, oxidative stress resistance and lifespan through the modulation of iron levels by inositolphosphosphingolipid phospholipase C (Isc1p) [90]. The most abundant intracellular divalent cation in yeast is magnesium, which acts primarily as an enzyme cofactor and correlation between cellular $\mathrm{Mg} 2+$ uptake and alcoholic fermentation in industrial strains of S. cerevisiae have also been demonstrated [91]. For the structure and functionality of $>300$ enzymes such as alcohol dehydrogenase (the terminal step in alcoholic fermentation), trace levels of zinc are essential. Zinc homeostasis, in S. cerevisiae is regulated by the controlled activity of zinc uptake transporters in the plasma membrane and transporters responsible for intracellular zinc compartmentalisation [92].

In rum production, the most common carbon source from the molasses is sucrose, with glucose also present in relatively high concentrations. For a source of nitrogen, S. cerevisiae requires a readily assimilable organic or inorganic form for growth and fermentative metabolism. Nitrogen is utilised in the biosynthesis of structural and functional proteins (enzymes) and nucleic acids, as well as in the production of fermentation flavour congeners such as higher alcohols. In distillery strains of $S$. cerevisiae, the levels of free $\alpha$-amino nitrogen (FAN) can be growth limiting, with growth rates reported to increase linearly with FAN levels up to a maximum of $100 \mathrm{mg} / \mathrm{L}$ FAN [93].

Although S. cerevisiae is referred to as a facultative anaerobe, it cannot grow under strictly anaerobic conditions. Oxygen is needed as a growth factor for the biosynthesis of membrane fatty acids (e.g., oleic acid) and sterols (e.g., ergosterol), with S. cerevisiae considered to be auxotrophic for oleic acid and ergosterol under anaerobic conditions. Therefore, to ensure effective alcoholic fermentation, either some oxygen can be provided at the start of the fermentation process, or the medium can be supplemented with these limiting fatty acids and sterol growth factors [45].

\subsection{Microbial Contamination}

Bacterial contamination is a major cause of decreased ethanol yield during the fermentation of starch-based or sugar-based feedstocks using S. cerevisiae. Sugar consumed by bacteria is diverted from the production of ethanol and converted into unwanted byproducts, such as lactic and acetic acid. In addition to this reduction in yield, the presence of bacterial metabolites in the fermentation medium has inhibitory effects on yeast growth 
and metabolism. In the distillery setting, it is important to identify potential sources of contamination and to identify the most frequently encountered contaminants, allowing adequate steps to be taken to reduce serious losses.

Bacterial contaminants encountered during fermentation include both Gram-positive and Gram-negative species. Amongst these, lactic acid bacteria are the most problematic due to their tolerance to high temperatures and low $\mathrm{pH}$, resulting in their ability to reproduce rapidly under conditions optimised for ethanol production from yeast. One of the main contaminants of molasses fermentation is Leuconostoc mesenteroides, which causes sucrose molecules to polymerise into unfermentable dextran chains. If the contamination is very extensive, the molasses may look 'ropey' due to this polymerisation process [3].

Another genus is of significant concern to distilleries and fuel ethanol plants is Lactobacillus. When bacterial numbers of Lactobacillus fermentis reach $10^{8} \mathrm{CFU} / \mathrm{mL}$ at $30 \mathrm{hrs}$ of fermentation, ethanol losses of approximately $5 \%$ have been noted [94,95]. When bacterial counts reached $4.5 \times 10^{8} \mathrm{CFU} / \mathrm{mL}$ at the same time point, this increased to a $17 \%$ reduction in ethanol yield [94]. Aside from the reduction in ethanol yield, contamination by lactic acid bacteria result in lower yeast counts, reduced carbohydrate utilization and increased acidity due to the build-up of lactic acid [96]. Furthermore, there may be competition with yeast cells for important growth factors in the fermentation medium. Methods used in the brewing industry to control bacterial contamination include rigorous cleaning and sanitation of equipment, adjustment of the fermentation medium to a lower $\mathrm{pH}$, and the use of antibiotics during fermentation. The choice of method(s) depends to a large extent on the end use of the alcohol produced, with cleaning and sanitisation typically the most suitable methods when distilling products for human consumption.

\subsection{Process Control and Optimization}

For an industrial fermentation process, the fermentation medium and process conditions play a critical role as they affect the formation, concentration and yield of particular fermentation end products (predominantly ethanol), thus influencing the overall process economics. It is therefore important to consider the optimisation of fermentation medium and process conditions in order to maximise the profits from fermentation. Increasing productivity reduces the overall cost of the product, as well as the production cost; hence, it is one of the important topics for this research. Enhanced productivity is usually achieved either by strain improvement or by optimising the process parameters.

\section{Future Directions and Conclusions}

The global popularity of alcoholic spirits, including rum, has grown enormously over the last century. The process of rum production is considered economically viable largely due to the low-cost availability of the key precursor material (i.e., molasses) to produce alcohol through the process of fermentation. However, most rum distilleries generally only reach about $80-85 \%$ of the potential ethanol available from the fermentable sugars present in molasses. This deficit equates to lost revenues for the manufacturer in wasted inputs. Moreover, it is evident that there are also significant inconsistencies in the yield of alcohol amongst differing batches of molasses utilised as raw materials for various fermentations.

Going forward, it would be prudent to investigate the plausible cause(s) that could be responsible for the low actual yield of ethanol and the subsequent observed inconsistencies in the fermentation outputs of various batches. Some of the key identifiable aspects that needs to be fully investigated in view of optimising alcohol and in turn rum production are yeast health and bacterial control; and the impact of molasses composition as the most likely theoretical factors that have the greatest impact on the fermentation efficiency. Process optimisation to maximise ethanol yield from molasses fermentation has the potential to result in both increased productivity and amount of saleable product, alongside a reduction in waste from unrealised ethanol conversion from molasses.

Supplementary Materials: The following are available online at https:/ /www.mdpi.com/2311-5 $637 / 7 / 1 / 21 / s 1$, Table S1: Typical concentrations of the major volatile compounds found in rum 
produced from sugar cane molasses, alongside their odour threshold and odour activity value (OAV). Structures are from ChemSpider (http:/ / www.chemspider.com/), ref [97-103] are cited in the supplementary materials file.

Author Contributions: Conception of review topic: M.N. Literature search and initial drafting of the manuscript: T.M. (Tinashe Mangwanda), J.B.J., J.S.M., M.N. Critical review and editing of manuscript: T.M. (Tinashe Mangwanda), J.B.J., J.S.M., S.J., S.C., T.M. (Tyryn McKeown), S.W., M.N. All authors read and approved the final version of the manuscript.

Funding: One of the authors (MN) acknowledges support from CQUniversity in the form of a New Staff Research Grant (RSH/5343).

Institutional Review Board Statement: Not applicable.

Informed Consent Statement: Not applicable.

Data Availability Statement: No new data were created or analyzed in this study. Data sharing is not applicable to this article.

Conflicts of Interest: Two of the authors (T.M. (Tyryn McKeown) sand S.J.) are affiliated with Bundaberg Rum Distillery. No other conflict of interest exist.

\section{References}

1. Pounder, P. Branding: A Caribbean perspective on rum manufacturing competitiveness. Int. J. Entrep. Small Bus. 2010, 9, 394-406. [CrossRef]

2. Pino, J.A. Characterization of rum using solid-phase microextraction with gas chromatography-mass spectrometry. Food Chem. 2007, 104, 421-428. [CrossRef]

3. Piggot, R. Treatment and fermentation of molasses when making rum-type spirits. In The Alcohol Textbook, 4th ed.; Kelsall, D., Jacques, K., Lyons, T., Eds.; Nottingham University Press: Nottingham, UK, 2003; pp. 75-84.

4. Leal, M. Ethanol production from cane resources. In Bioenergy for Sustainable Development and International Competitiveness: The Role of Sugar Cane in Africa; Johnson, F.X., Seebaluck, V., Eds.; Routledge: New York, NY, USA, 2012; pp. $126-157$.

5. Lisle, P. Rum beginnings: Towards a new perspective of the Grose years. J. R. Aust. Hist. Soc. 2005, 91, 15-28.

6. Nicol, D. Rum. In Fermented Beverage Production, 2nd ed.; Lea, A.G., Piggott, J.R., Eds.; Springer: Boston, MA, USA, 2003.

7. Liberman, A. The Rum History of the Word "Rum". Available online: https://blog.oup.com/2010/10/rum/ (accessed on 17 November 2020).

8. FSANZ (Food Standards Australia \& New Zealand). Standard 2.7.5—Spirits; Technical Report No. 2.7.5; FSANZ: Canberra, Australia, 2000.

9. Australian Distillers Association. Guidance Summary: Legal Definitions of Brandy, Rum, Whisky; Australian Distillers Association: Sydney, Australia, 2017.

10. US Government. 27 CFR and 5.22-The Standards of Identity; US Government: Washington, WA, USA, 2010.

11. The Council of European Communities. Appellations of Origin (Spirit Drinks) Council Regulations; Technical Report No. 1576/89; The Council of European Communities: Brussels, Belgium, 1989.

12. CROSQ (CARICOM Regional Organisation for Standards and Quality). CARICOM Regional Standard for Rum: Specifications; Technical Report No. CRS 25: 2008; CARICOM: Belleville, St Michael, Barbados, 2008.

13. Murtagh, J.E. Feedstocks, fermentation and distillation for production of heavy and light rums. In The Alcohol Textbook, 4th ed.; Kelsall, D., Jacques, K., Lyons, T., Eds.; Nottingham University Press: Nottingham, UK, 2003; pp. $243-255$.

14. Fahrasmane, L.; Parfait, A. Rum. In Encyclopedia of Food Sciences and Nutrition, 2nd ed.; Caballero, B., Ed.; Academic Press: Oxford, UK, 2003; pp. 5021-5027. [CrossRef]

15. Medeiros, A.B.P.; de Matos, M.E.; de Pinho Monteiro, A.; de Carvalho, J.C.; Soccol, C.R. 16-Cachaça and Rum. In Current Developments in Biotechnology and Bioengineering; Pandey, A., Sanromán, M.Á., Du, G., Soccol, C.R., Dussap, C.-G., Eds.; Elsevier: Amsterdam, The Netherlands, 2017; pp. 451-468. [CrossRef]

16. Furiassi, C. Towards a glossary of rum making and rum tasting. In Proceedings of the XVIII EURALEX International Congress, Ljubljana, Slovenia, 17-21 July 2018; p. 139.

17. Statista. Rum: Worldwide. Available online: https://www.statista.com/outlook/10020300/100/rum/worldwide (accessed on 8 December 2020).

18. Hamrick, D.; Fernandez-Stark, K. Barbados in the Rum Global Value Chain; Duke Global Value Chain Center, Duke University: Durham, NC, USA, 2017.

19. Pandey, V.C.; Bajpai, O.; Pandey, D.N.; Singh, N. Saccharum spontaneum: An underutilized tall grass for revegetation and restoration programs. Genet. Resour. Crop Evol. 2015, 62, 443-450. [CrossRef]

20. Castro, S.G.Q.D.; Franco, H.C.J.; Mutton, M.Â. Harvest managements and cultural practices in sugarcane. Rev. Bras. Ciência Solo 2014, 38, 299-306. [CrossRef] 
21. Park, M.J.; Jo, J.H.; Park, D.; Lee, D.S.; Park, J.M. Comprehensive study on a two-stage anaerobic digestion process for the sequential production of hydrogen and methane from cost-effective molasses. Int. J. Hydrog. Energy 2010, 35, 6194-6202. [CrossRef]

22. Coelho, C.; Brottier, C.; Beuchet, F.; Elichiry-Ortiz, P.; Bach, B.; Lafarge, C.; Tourdot-Maréchal, R. Effect of ageing on lees and distillation process on fermented sugarcane molasses for the production of rum. Food Chem. 2020, 303, 125405. [CrossRef]

23. Fleet, G.H.; Green, V. The microbiology and biotechnology of rum production. In Distilled Spirits, Volume 3: New Horizons: Energy, Environment and Enlightenment; Nottingham University Press: Nottingham, UK, 2010; Volume 3, p. 203.

24. Jevtić-Mučibabić, R.; Grbić, J.; Mišljenović, N.; Koprivica, G.; Kuljanin, T.; Radivojević, S. Nitrogen compounds in the molasses. J. Process. Energy Agric. 2011, 15, 169-172.

25. Schoonees, B.; Pillay, V. A New Filtration system for gum analysis in raw sugar and molasses. Proc. South Afr. Sugar Technol. Assoc. 2004, 78, 565-568.

26. Kampen, W.H. Chapter 4-Nutritional Requirements in fermentation processes. In Fermentation and Biochemical Engineering Handbook, 3rd ed.; Vogel, H.C., Todaro, C.M., Eds.; William Andrew Publishing: Boston, MA, USA, 2014; pp. 37-57. [CrossRef]

27. Olbrich, H. The Molasses; Biotechnologie-Kempe GmbH: Berlin, Germany, 1963; p. 128.

28. Jones, A.M.; Thomas, K.C.; Ingledew, W.M. Ethanolic Fermentation of Blackstrap molasses and sugarcane juice using very high gravity technology. J. Agric. Food Chem. 1994, 42, 1242-1246. [CrossRef]

29. Quesada-Granados, J.J.; Samaniego-Sánchez, C.; Blanca-Herrera, R.M. Rhum-ron-rum: Technology and tradition. In Encyclopedia of Food and Health; Caballero, B., Finglas, P.M., Toldrá, F., Eds.; Academic Press: Oxford, UK, 2016; pp. 618-627. [CrossRef]

30. Abubaker, H.O.; Sulieman, A.M.E.; Elamin, H.B. Utilization of Schizosaccharomyces pombe for production of ethanol from cane molasses. J. Microbiol. Res. 2012, 2, 36-40. [CrossRef]

31. Paturau, J.M. By-Products of the Cane Sugar Industry. An Introduction to Their Industrial Utilization; Elsevier Science Publishers BV: Amsterdam, The Netherlands, 1989.

32. Wiebe, H.H.; Kidambi, R.N.; Richardson, G.H.; Ernstrom, C.A. A Rapid Psychrometric procedure for water activity measurement of foods in the intermediate moisture range. J. Food Prot. 1981, 44, 892-895. [CrossRef] [PubMed]

33. Ghorbani, F.; Younesi, H.; Esmaeili Sari, A.; Najafpour, G. Cane molasses fermentation for continuous ethanol production in an immobilized cells reactor by Saccharomyces cerevisiae. Renew. Energy 2011, 36, 503-509. [CrossRef]

34. Li, H.; Jiang, Z.; Yang, X.; Yu, L.; Zhang, G.; Wu, J.; Liu, X. Sustainable resource opportunity for cane molasses: Use of cane molasses as a grinding aid in the production of Portland cement. J. Clean. Prod. 2015, 93, 56-64. [CrossRef]

35. Clarke, M. Syrups. In Encyclopedia of Food Science; Sugar Processing Research Institute Incorporated: New Orleans, LA, USA, 1993; pp. 5711-5717.

36. Nelson, E.K. Some organic acids of sugar cane molasses. J. Am. Chem. Soc. 1929, 51, 2808-2810. [CrossRef]

37. Yoder, P.A. Notes on the determination of acids in sugar cane juice. J. Ind. Eng. Chem. 1911, 3, 640-646. [CrossRef]

38. Binkley, W.W.; Wolform, M.L. Composition of Cane juice and cane final molasses. In Advances in Carbohydrate Chemistry; Hudson, C.S., Wolfrom, M.L., Eds.; Academic Press: Cambridge, MA, USA, 1953; Volume 8, pp. 291-314.

39. Lehtonen, M.; Suomalainen, H. Rum. In Economic Microbiology; Rose, A., Ed.; Academic Press: Cambridge, MA, USA, 1977; Volume 1, pp. 595-633.

40. Lea, A.G.; Piggott, J.R. Fermented Beverage Production, 2nd ed.; Kluwer Academic: New York, NY, USA, 2003.

41. Walker, G.M. Metals in yeast fermentation processes. In Advances in Applied Microbiology; Laskin, A.I., Bennett, J.W., Gadd, G.M., Eds.; Elsevier Academic Press: San Diego, CA, USA, 2004; pp. 197-230.

42. Siqueira, P.F.; Karp, S.G.; Carvalho, J.C.; Sturm, W.; Rodríguez-León, J.A.; Tholozan, J.-L.; Singhania, R.R.; Pandey, A.; Soccol, C.R. Production of bio-ethanol from soybean molasses by Saccharomyces cerevisiae at laboratory, pilot and industrial scales. Bioresour. Technol. 2008, 99, 8156-8163. [CrossRef] [PubMed]

43. Singh, V.; Haque, S.; Niwas, R.; Srivastava, A.; Pasupuleti, M.; Tripathi, C.K.M. Strategies for fermentation Medium optimization: An in-depth review. Front. Microbiol. 2017, 7. [CrossRef]

44. Bluhm, L. Distilled beverages. In Biotechnology, a Comprehensive Treatise in 8 Volumes; Rehm, H.-J., Reed, G., Eds.; Verlag Chemie: Weinheim, Germany, 1983; Volume 5, pp. 447-475.

45. Walker, G.M.; Stewart, G.G. Saccharomyces cerevisiae in the Production of fermented beverages. Beverages 2016, 2, 30. [CrossRef]

46. Goksel, M.; Dogan, M.; Toker, O.S.; Ozgen, S.; Sarioglu, K.; Oral, R.A. The Effect of starch concentration and temperature on Grape molasses: Rheological and Textural properties. Food Bioprocess Technol. 2013, 6, 259-271. [CrossRef]

47. Greetham, D.; Hart, A.J.; Tucker, G.A. Presence of low concentrations of acetic acid improves yeast tolerance to hydroxymethylfurfural (HMF) and furfural. Biomass Bioenergy 2016, 85, 53-60. [CrossRef]

48. Casey, E.; Sedlak, M.; Ho, N.W.Y.; Mosier, N.S. Effect of acetic acid and pH on the cofermentation of glucose and xylose to ethanol by a genetically engineered strain of Saccharomyces cerevisiae. Fems Yeast Res. 2010, 10, 385-393. [CrossRef]

49. Ferreira, M.M.; Loureiro-Dias, M.C.; Loureiro, V. Weak acid inhibition of fermentation by Zygosaccharomyces bailii and Saccharomyces cerevisiae. Int. J. Food Microbiol. 1997, 36, 145-153. [CrossRef]

50. Laluce, C.; Leite, G.R.; Zavitoski, B.Z.; Zamai, T.T.; Ventura, R. Fermentation of sugarcane juice and molasses for ethanol production. In Sugarcane-Based Biofuels and Bioproducts; Wiley: Hoboken, NJ, USA, 2016; pp. 53-86.

51. Bortolussi, G.; O’Neill, C.J. Variation in molasses composition from eastern Australian sugar mills. Aust. J. Exp. Agric. 2006, 46, 1455-1463. [CrossRef] 
52. Lingle, S.E.; Wiegand, C.L. Soil salinity and sugarcane juice quality. Field Crop. Res. 1997, 54, 259-268. [CrossRef]

53. Shukla, S.K.; Solomon, S.; Sharma, L.; Jaiswal, V.P.; Pathak, A.D.; Singh, P. Green technologies for improving cane sugar productivity and sustaining soil fertility in sugarcane-based cropping system. Sugar Tech. 2019, 21, 186-196. [CrossRef]

54. Alamilla-Magaña, J.C.; Carrillo-Ávila, E.; Obrador-Olán, J.J.; Landeros-Sánchez, C.; Vera-Lopez, J.; Juárez-López, J.F. Soil moisture tension effect on sugar cane growth and yield. Agric. Water Manag. 2016, 177, 264-273. [CrossRef]

55. Franitza, L.; Granvogl, M.; Schieberle, P. Influence of the Production process on the key aroma compounds of rum: From molasses to the spirit. J. Agric. Food Chem. 2016, 64, 9041-9053. [CrossRef] [PubMed]

56. Murtagh, J.E. Molasses as a feedstock for alcohol production. In The Alcohol Textbook; Lyons, T., Kelsall, D., Murtagh, J.E., Eds.; Nottingham University Press: Nottingham, UK, 1995.

57. Hill, A.E. Deciphering dunder: An examination of rum fermentation. In Proceedings of the Worldwide Distilled Spirits Conference: Local Roots; Global Reach: Delivering Distilling Expertise to the World, Glasgow, UK, 29 May-1 June 2017.

58. Hutzler, M.; Koob, J.; Riedl, R.; Schneiderbanger, H.; Mueller-Auffermann, K.; Jacob, F. 5-yeast identification and characterization. In Brewing Microbiology; Hill, A.E., Ed.; Woodhead Publishing: Cambridge, UK, 2015; pp. 65-104. [CrossRef]

59. Fahrasmane, L.; Ganou-Parfait, B. Microbial flora of rum fermentation media. J. Appl. Microbiol. 1998, 84, 921-928. [CrossRef]

60. Suomalainen, $\mathrm{H}$. Some general aspects of the composition of alcoholic beverages [Quelques aspects généraux de la composition des boissons alcooliques]. Ann. Technol. Agric. 1975, 24, 453-467.

61. Broom, D. Rum; Abbeville Press: New York, NY, USA, 2003.

62. Piggott, J. Distillation of brandies. In The Alcohol Textbook, 5th ed.; Nottingham University Press: Nottingham, UK, 2009; pp. 491-506.

63. Jacques, K.; Lyon, T.; Kelsall, D. The Alcohol Textbook, 4th ed.; Nottingham University Press: Nottingham, UK, 2003.

64. Berry, D.R.; Slaughter, J.C. Alcoholic Beverage fermentations. In Fermented Beverage Production; Lea, A.G.H., Piggott, J.R., Eds.; Springer: Boston, MA, USA, 2003; pp. 25-39. [CrossRef]

65. Madrera, R.R.; Gomis, D.B.; Alonso, J.J.M. Influence of Distillation system, oak wood type, and aging time on volatile compounds of cider brandy. J. Agric. Food Chem. 2003, 51, 5709-5714. [CrossRef] [PubMed]

66. Reche, R.V.; Leite Neto, A.F.; Da Silva, A.A.; Galinaro, C.A.; De Osti, R.Z.; Franco, D.W. Influence of Type of distillation apparatus on chemical profiles of Brazilian cachaças. J. Agric. Food Chem. 2007, 55, 6603-6608. [CrossRef] [PubMed]

67. Zitting, A.; Savolainen, H.; Nickels, J. Biochemical and toxicological effects of single and repeated exposures to polyacetal thermodegradation products. Environ. Res. 1982, 29, 287-296. [CrossRef]

68. Spaho, N.; Dürr, P.; Grba, S.; Velagić-Habul, E.; Blesić, M. Effects of distillation cut on the distribution of higher alcohols and esters in brandy produced from three plum varieties. J. Inst. Brew. 2013, 119, 48-56. [CrossRef]

69. Bamforth, C.W.; Ward, R.E. The Oxford Handbook of Food Fermentations; Oxford University Press: Oxford, UK, 2014.

70. Clutton, D. Rum. Flavour Ind. 1974, 5, 286-288.

71. Mosedale, J.R. Effects of oak wood on the maturation of alcoholic beverages with particular reference to whisky. For. Int. J. For. Res. 1995, 68, 203-230. [CrossRef]

72. Mosedale, J.R.; Puech, J.L. Wood maturation of distilled beverages. Trends Food Sci. Technol. 1998, 9, 95-101. [CrossRef]

73. De Rosso, M.; Cancian, D.; Panighel, A.; Dalla Vedova, A.; Flamini, R. Chemical compounds released from five different woods used to make barrels for aging wines and spirits: Volatile compounds and polyphenols. Wood Sci. Technol. 2009, 43, 375-385. [CrossRef]

74. Coldea, T.E.; Mudura, E.; Socaciu, C. Advances in distilled beverages authenticity and quality testing. In Ideas and Applications toward Sample Preparation for Food and Beverage Analysis; Stauffer, M.T., Ed.; IntechOpen: London, UK, 2017; pp. 109-130. [CrossRef]

75. Quesada Granados, J.; Merelo Guervós, J.J.; Oliveras López, M.J.; González Peñalver, J.; Olalla Herrera, M.; Blanca Herrera, R.; López Martinez, M.C. Application of Artificial aging techniques to samples of rum and comparison with traditionally aged rums by analysis with artificial neural nets. J. Agric. Food Chem. 2002, 50, 1470-1477. [CrossRef]

76. Fernández de Simón, B.; Cadahía, E. Volatile compounds in a Rioja wine aged in Spanish, French and American oak barrels. In Proceedings of the Congresos y Jornadas-Gobierno de La Rioja (España), Logroño, Spain, 21-23 May 2003.

77. Remmer, C. Differences between Swedish, French and American Oak when Storing Whisky Analysed by GC-MS. Bachelor's Thesis, Örebro University, Örebro, Sweden, 2015.

78. Pino, J.A.; Tolle, S.; Gök, R.; Winterhalter, P. Characterisation of odour-active compounds in aged rum. Food Chem. 2012, 132, 1436-1441. [CrossRef] [PubMed]

79. Franitza, L.; Granvogl, M.; Schieberle, P. Characterization of the Key aroma compounds in two commercial rums by means of the sensomics approach. J. Agric. Food Chem. 2016, 64, 637-645. [CrossRef] [PubMed]

80. Herranz, A.; de la Serna, P.; Barro, C.; Martin-Alvarez, P.J. Multivariate statistical methods applied to the differentiation of rum brands. J. Sci. Food Agric. 1990, 51, 555-560. [CrossRef]

81. Nykänen, L.; Puputti, E.; Suomalainen, H. Volatile Fatty acids in some brands of whisky, cognac and rum. J. Food Sci. 1968, 33, 88-92. [CrossRef]

82. Piggott, J. Alcoholic Beverages: Sensory Evaluation and Consumer Research; Elsevier: Amsterdam, The Netherlands, 2011.

83. Kourtis, L.K.; Arvanitoyannis, I.S. Implementation of hazard analysis critical control point (HACCP) system to the alcoholic beverages industry. Food Rev. Int. 2001, 17, 1-44. [CrossRef] 
84. Chikhoune, A.; Bedjou, F.; Oubouzid, S.; Boukefoussa, R.; Bechri, B.; Tarmoul, H.; Abdeladim, T.; Tounsi, A.; Hamitri, M.; Chikh, S.; et al. Development of sugar cane molasses in formulations of madeleines, mini croissants, and buns incorporated with interesterified oil. J. Chem. 2014, 2014, 936780. [CrossRef]

85. Deseo, M.A.; Elkins, A.; Rochfort, S.; Kitchen, B. Antioxidant activity and polyphenol composition of sugarcane molasses extract. Food Chem. 2020, 314, 126180. [CrossRef] [PubMed]

86. Palmonari, A.; Cavallini, D.; Sniffen, C.J.; Fernandes, L.; Holder, P.; Fagioli, L.; Fusaro, I.; Biagi, G.; Formigoni, A.; Mammi, L. Short communication: Characterization of molasses chemical composition. J. Dairy Sci. 2020, 103, 6244-6249. [CrossRef] [PubMed]

87. Pierce, J.S. Horace Brown memorial lecture the role of nitrogen in brewing. J. Inst. Brew. 1987, 93, 378-381. [CrossRef]

88. Hohmann, S. Osmotic Stress signaling and osmoadaptation in yeasts. Microbiol. Mol. Biol. Rev. 2002, 66, 300-372. [CrossRef] [PubMed]

89. O'Connor-Cox, E.S.C.; Ingledew, W.M. Wort nitrogenous sources-Their use by brewing yeasts: A review. J. Am. Soc. Brew. Chem. 1989, 47, 102-108. [CrossRef]

90. Almeida, T.; Marques, M.; Mojzita, D.; Amorim, M.A.; Silva, R.D.; Almeida, B.; Rodrigues, P.; Ludovico, P.; Hohmann, S.; Moradas-Ferreira, P.; et al. Isc1p Plays a key role in hydrogen peroxide resistance and chronological lifespan through modulation of iron levels and apoptosis. Mol. Biol. Cell 2008, 19, 865-876. [CrossRef] [PubMed]

91. Walker, G.M. Yeast Physiology and Biotechnology; John Wiley \& Sons: Hoboken, NJ, USA, 1998.

92. Eide, D.J. Multiple Regulatory mechanisms maintain zinc homeostasis in Saccharomyces cerevisiae. J. Nutr. 2003, 133, 1532S-1535S. [CrossRef] [PubMed]

93. Ingledew, W. Alcohol production by Saccharomyces cerevisiae: A yeast primer. In The Alcohol Textbook; Lyons, T., Kelsall, D., Eds.; Nottingham University Press: Nottingham, UK, 1999; Volume 3, pp. $49-87$.

94. Barbour, E.; Priest, F. Some effects of Lactobacillus contamination in scotch whisky fermentations. J. Inst. Brew. 1988, 94, 89-92. [CrossRef]

95. Dolan, T.C.S. Some Aspects of the impact of brewing science on scotch malt whisky production. J. Inst. Brew. 1976, 82, 177-181. [CrossRef]

96. Makanjuola, D.B.; Tymon, A.; Springham, D.G. Some effects of lactic acid bacteria on laboratory-scale yeast fermentations. Enzym. Microb. Technol. 1992, 14, 350-357. [CrossRef]

97. Meilgaard, M.C. Flavor chemistry of beer. II. Flavor and threshold of 239 aroma volatiles. Tech. Quart. Master. Brew. Assoc. Am. 1975, 12, 151-168.

98. Uselmann, V.; Schieberle, P. Decoding the combinatorial aroma code of a commercial cognac by application of the sensomics concept and first insights into differences from a German brandy. J. Agric. Food Chem. 2015, 63, 1948-1956. [CrossRef] [PubMed]

99. Czerny, M.; Christlbauer, M.; Christlbauer, M.; Fischer, A.; Granvogl, M.; Hammer, M.; Hartl, C.; Hernandez, N.M.; Schieberle, P. Re-investigation on odour thresholds of key food aroma compounds and development of an aroma language based on odour qualities of defined aqueous odorant solutions. Eur. Food Res. Technol. 2008, 228, 265-273. [CrossRef]

100. Poisson, L.; Schieberle, P. Characterization of the key aroma compounds in an American bourbon whisky by quantitative measurements, aroma recombination, and omission studies. J. Agric. Food Chem. 2008, 56, 5820-5826. [CrossRef] [PubMed]

101. Willner, B.; Granvogl, M.; Schieberle, P. Characterization of the key aroma compounds in Bartlett pear brandies by means of the sensomics concept. J. Agric. Food Chem. 2013, 61, 9583-9593. [CrossRef]

102. Suomalainen, H.; Nykänen, L. Investigations on the aroma of alcoholic beverages. Naeringsmiddelindustrien 1970, $23,15-30$.

103. Otsuka, K.-I.; Zenibayashi, Y.; Itoh, M.; Totsuka, A. Presence and significance of two diastereomers of $\beta$-methyl- $\gamma$-octalactone in aged distilled liquors. Agric. Biol. Chem. 1974, 38, 485-490. [CrossRef] 